\title{
Regional capabilities and the European employment strategy
}

\author{
Martin Heidenreich
}

\section{The Regional Dimension of the European Employment Strategy}

The European Council laid the foundations for a European Employment Strategy (EES) in Amsterdam (June 1997) by anchoring the promotion of high employment levels and "the promotion of co-ordination between employment policies of the Member States with a view to enhancing their effectiveness” in Articles 2 and 3 of the EC Treaty (cf. Goetschy 1999, Keller 2000, Hassel and Hoffmann 2000, Platzer 1999, Mosher and Trubeck 2003). This strategy was designed to improve the integration of groups, which are currently underrepresented, into the labour market. Women, older workers, the long-term unemployed, young people, early school leavers, low-skilled workers, people with disabilities, immigrants and ethnic minorities are explicitly mentioned in the latest Employment Guidelines (2003). The creation of a more inclusive national employment order is especially pursued through a new, more open method of co-ordination that is based on the definition of common targets, and a common evaluation of the outcomes and mutual learning processes (cf. Pochet, in this volume; Hodson and Maher 2001; de la Porte, Pochet and Room 2001, Scharpf 2002, Ferrera et al. 2002).

Initially, the EES was mainly focused on the national level. Subsequently, in 2000, the foundations for local and regional employment policies were laid. Since 2000, the importance of the regional level has not only been emphasised in the employment guidelines. Communication No. 196/2000 of the European Commission also calls for a "local dimension for the European employment strategy". This was legitimated with a high share of government expenditures at the local and regional level, the employment potential of smaller businesses, and with the large impact of the third sector; the non-profit organisations.

Until now, the effects of this decentralisation have been extremely limited, according to the Commission as stated in a recent evaluation of the EES. ${ }^{1}$ This may be the result of

\footnotetext{
"Since European policies tend to reach the local level not so much at the policy track but in the context of funding operations, respective incentive measures and, particularly the ESF, have played a major role (...) The EES, which is itself partnership based, tries to stimulate a partnership approach also at local level, visible for instance in the promotion of Local Action Plans for Employment (LAP), which proved that such an approach is feasible. Local authorities are expected to play a major role in this context, but there is still a significant lack of information not only with regard to techniques and instruments, but
} 
defining a given region too narrowly - a definition that focuses on the social and ignores the productive dimension of the respective region. Regional employment and unemployment disparities are at the centre of the regional dimension of the EES. ${ }^{2}$ Regions are considered as areas of social services and social exclusion, but not as areas of entrepreneurial activities and innovation strategies. The Commission seeks and promotes the involvement of regional and local authorities, public employment services, social partners and civil society, but is does not mention the involvement of entities such as regional companies and business associations. Regional innovation policies are also not mentioned (cf. R. Villeneuve, in this volume). The productive and economic prerequisites for the creation of regional jobs have not yet been incorporated into the EES. Thus, it risks limiting the territorial dimension of the EES to a mere symbolic practice or to a policy, which mainly exists to redistribute funds (via the structural funds).

My thesis is that a more comprehensive approach to regional employment and unemployment policies requires that the region has to be regarded as a productive system that may be characterized by a set of horizontally and vertically interrelated companies and a regional order (public authorities, educational facilities, research and development institutes, industrial relations and business associations ...) facilitating the creation of new and the recombination and path-dependent development of existing productive capabilities. By these means, the productive bases of regional disparities can be directly addressed without having to rely merely on redistribution policies. Regional capabilities are the crucial basis for regional employment. Regional employment strategies therefore should not only concentrate on redistribution and on patterns of social exclusion, but should also address the origins of unsatisfactory regional employment performance by enhancing regional productive competences.

also with regard to their role as such (...) The role of the social partners in local strategies is less pronounced, and that of businesses and other groups in society even less.” (Impact evaluation of the European employment strategy supporting COM(2002) 416))

2 In the Commission proposal for the "Guidelines for employment policies of the Member States” (2003) it is stated: "Member States should implement a broad approach towards reducing regional employment and unemployment disparities. The potential for job creation at the local level, including in the social economy, should be supported and partnerships between all relevant actors should be encouraged. Member States will:

- $\quad$ promote favourable conditions for private sector activity and investment in regions lagging behind;

- $\quad$ ensure that public support in regions lagging behind is focused on investment in human and knowledge capital, as well as adequate infrastructure.

The potential of the Cohesion and Structural Funds and the European Investment Bank should be fully exploited.” (http://europa.eu.int/comm/employment_social/employment_strategy/prop_2003/gl_en.pdf; accessed on July $17^{\text {th }}$, 2003). 
There is also a second way in which the EES could profit from an increased involvement at the regional level. In the third section of this article, we will show that more inclusive labour market regimes are empirically linked to higher educational levels and more knowledge-based forms of production (for example advanced services). Supporting regional production networks, therefore, may also be an indirect way of increasing the inclusiveness of labour markets.

This regional capability approach, which is based on the analysis of regional innovation systems (Braczyk et al. 1998), is only indirectly related to the capability approach of Amartya Sen underlying other contributions to this volume. While Sen concerns himself with the individual capabilities reflecting "the alternative combinations of functionings the person can achieve, and from which he or she can choose one collection” (Sen 1993: 31), we are more interested in collectively created and institutionally and organizationally reproduced productive competences.

This paper will address the evolution of regional capabilities and their link to labour market structures in three steps. In the following section, the institutional and organisational bases of regional capabilities and their path-dependent evolution will briefly be summarised (2). Then we will analyse the two-dimensional structure of regional capabilities and discuss their possible connection to regional patterns of labour market exclusion (3). In the last step, we will address the possibilities of political support for regional innovation systems (4).

\section{The Evolution of Regional Capabilities}

The regional concentration of industrial competencies is a well-known phenomenon - at least since the classic work of the British economist Alfred Marshall. Observing the early industrial districts of England, he wrote: "The mysteries of the trade become no mystery; but are as it were in the air (...) Good work is rightly appreciated, inventions and improvements in machinery, in processes and the general organisation of the business have their merits promptly discussed: if one man starts a new idea, it is taken up by others and combined with suggestions of their own; and thus it becomes the source of further ideas” (Marshall 1982: 225; originally published in 1890). These regional capabilities are not a characteristic of early industrialisation. Nowadays, industrial competencies are still regionally concentrated. This is true for traditional industries as well as for the information technology and multimedia industry, finance services, advertising and for biotechnology. In Germany for instance, the multimedia industry is concentrated in Cologne, Munich and recently in Berlin; and the 
microchip industry is based in Munich and Dresden and their immediate surrounding areas. In Hamburg, the advertising industry plays a considerable role in the city-state's economy, and nearly all German kitchens are manufactured in eastern Westphalia. The automobile and mechanical engineering industries are of major importance in the Stuttgart region, and the German biotechnology industry is concentrated in Munich and around Heidelberg. Financial services are concentrated in Frankfurt, textile mechanical engineering in the region of Krefeld, and medical technology and instruments are produced in the Tuttlingen region.

This regional concentration and accumulation of industrial capabilities is addressed in the discussion on industrial districts, on regional and national clusters (Cooke 2002), on learning regions and regional innovation systems (Storper and Salais 1997; Braczyk et al. 1998; see the overview in Storper 1997 and Amin 1999). While the discussion on clusters is focussed on the industrial structure of a region and the existence of territorially concentrated, socio-culturally embedded and institutionally stabilized inter-organizational networks, that facilitate the accumulation, recombination and utilization of technical knowledge in specific technological fields, the discussion on regional innovation systems addresses the institutional order of a region and the provision of regional "collective competition goods” (Le Galès and Voelzkow 2001).

These regional innovation systems (RIS) can be defined as "places where close interfirm communication, socio-cultural structures and institutional environment may stimulate socially and territorially embedded collective learning and continuous innovation (...) Basically, regional innovation system consists of two main types of actors and the interaction between them ... The first actors are the firms in the main industrial cluster in a region including their support industries. Secondly, an institutional infrastructure must be present, i.e., research and higher education institutes, technology transfer agencies, vocational training organisations, business associations, finance institutions etc., which hold important competence to support regional innovation“ (Asheim and Isaksen 2002: 83-84).

The basis of regional capabilities is the experiences and the implicit knowledge that regional businesses and employees have accumulated through their close involvement in the production of a specific product or the use of a specific technology. Such implicit, contextspecific, non-tradable competencies can best be passed on through direct interactions and regional co-operation networks facilitated by close geographic proximity. Regional capabilities therefore are anchored in the institutions and networks that facilitate such patterns of interorganisational learning. 
Regional capabilities are not only the result of current organizational or political strategies. Many regional case studies have demonstrated that regional capabilities are developed in a sometimes century-long history of cooperation and competition, and that accidental factors often have a much stronger impact than planned political interventions. Regional trajectories, regional variation, selection, and stabilisation processes (cf. Cooke 1998a; Nelson 1995), sub-optimal, cumulative and path-dependent learning processes (Edquist 1997) and regional inertia and lock-in-effects have to be taken into account so as not to overestimate the contribution of a regional innovation policy for the role it plays in improving the performance of regional employment. An evolutionary framework is useful because it points to the limits of political interventions. Simply put, not every major university can establish a biotechnology district, and not every country can establish a Silicon Valley or a global financial services centre.

An evolutionary perspective on regional innovation systems has to show what the basic units of the regional innovation system are and what the "mechanisms" of regional variation, selection and stabilisation processes are. First, similar to organisational rules and routines that determine the capabilities of organisations (cf. Chandler 1992; Teece 1998; Teece, Pisano and Shuen 1997), the capabilities of a region are anchored in institutionally stabilised patterns of co-operation and competition shaping the mutual expectations between actors (Storper and Salais 1997). These rules or conventions can be considered as the "memory" (or - in a metaphorical way: the genome) of a region; they are the result of longlasting inter-organisational experiences of co-operation and conflict. The accumulation of implicit knowledge of a region results from these recursive processes of interaction. These are crucial for shaping the learning and innovation opportunities that regional firms have.

Second, the variation of regional capabilities requires the development of new intercompany patterns of relationship and co-operation. This can be accomplished, for example, through the creation of start-ups or new regional institutions.

Third, new patterns of relationships can be more easily established when they have the benefit of being able to rely upon previous regional capabilities, relationships and institutions (selection). This refers to the path-dependent nature of regional capabilities. Previously developed productive capabilities constrain certain trajectories and facilitate the development of other capabilities. For instance, a region like Stuttgart, which is dominated by the automobile, electronics and mechanical engineering industries, film, entertainment and multimedia firms would have very few opportunities to co-operate with established industrial 
companies. This would considerably reduce their chances of survival. On the other hand, the chances for production-related services would be excellent (Strambach 2002).

Fourth, patterns of co-operation and learning between firms can be stabilized by regional institutions or governance structures (stabilisation). Ethnic or professional communities are possible means for attaining such a stabilization. Such a phenomenon has been demonstrated in the central Italian industrial districts, the former Parisian and New York clothing districts and the current Frankfurt banking milieu. An alternative to such a sociocultural basis of trust is the idea of regional and national institutions such as the employers' professional and business associations, trade unions, schools and universities, public research, and development institutions or public technology transfer institutions, which work to stabilise regional patterns of communication, cooperation and mutual learning by the provision of collective competition goods.

In conclusion, regional capabilities are a possible focus for strategies, which could be implemented to improve the regional employment and unemployment situation. Regional capabilities are one example of a collective investment in people's capabilities, which are at the centre of Sen's and Salais' capability approach. The goal of this approach is not only to increase the number of regional jobs, but also to increase the technical content, the innovativeness and the sustainability of these jobs. While an employment-centred approach tries to reduce individual and regional disparities in income and employment opportunities, a capability approach tries to increase the quality of these jobs by, among other methods, the creation of a collective investment in regional productive competencies (in the sense of the high-road strategies analysed by Sabel et al. 1989). Such investments have to take the evolutionary, path-dependent nature of regional capabilities into account.

In the next section, we will argue that a shift from an employability-centred to a capability-centred approach may also be useful for another crucial objective of the European Employment Strategy; the creation of more inclusive labour markets.

\section{Regional Capabilities in Europe. Is there a link between innovativeness and inclusion?}

The European Employment Strategy aims to improve the employment possibilities, especially for females, and younger and older people, thus making the European labour market regimes more inclusive, shifting the balance from family- and state-based forms of welfare to marketbased incomes. In the framework of the classical American sociology, this could be characterized as a project of societal modernisation shift from particularistic to universalistic 
orientations, from ascription to achievement, from diffuse to specific obligations. This intended modernisation of European labour markets can be criticised from two, partially complementary points of view: First, this project ignores the existence of path-dependent patterns of evolution: The central objective of European employment strategies is a higher inclusion of females, older and younger people - and this means a radical change especially for Mediterranean and continental-European labour market regimes. Second, if such a shift from exclusive to inclusive labour markets is nevertheless possible, it may undermine the specific competencies linked to exclusive, segmented labour markets (for example internal, professional or vocational labour markets). The strategies of social closure, which are the principal target of employability-centred strategies, are also the basis for specific industrial relations and strategies which have been analysed as flexible production (Piore and Sabel 1984), “diversified quality production” (Streeck 1991) or "coordinated market economies" (Hall and Soskice 2001). More inclusive labour markets also require a different institutional and organizational environment; a different production model. A employability-centred strategy ,such as the one implemented by EES, cannot be implemented without the development of different forms of regional capabilities.

In the following, this thesis will be discussed based on the available regional data for the so-called NUTS-2 regions of the European Union. ${ }^{3}$ On this basis the diversity of regional capabilities and the corresponding patterns of exclusion and inclusion can be analysed, even if longer time series are not available and even if the available indicators for regional capabilities are extremely limited.

The nomenclature of territorial units for statistics (NUTS) established by Eurostat is a hierarchical classification that subdivides the Member States of the European Union into 78 regions at NUTS-1 level and 211 regions at NUTS-2 level. The United Kingdom, for example, is subdivided in 12 government office regions and 37 counties or groups of unitary authorities. 
Table 1: $\quad$ The two-dimensional structure of regional capabilities in 203 European Regions. The results of a factor analysis

\begin{tabular}{|c|c|c|c|c|c|}
\hline & \multicolumn{2}{|c|}{ Descriptive Statistics } & \multicolumn{3}{|c|}{ Factor analysis } \\
\hline & $\begin{array}{c}\text { Mean } \\
\text { (weighted) }\end{array}$ & $\begin{array}{l}\text { Standard } \\
\text { deviation } \\
\text { (weighted) }\end{array}$ & $\begin{array}{l}\text { Factor } \\
\text { loadings of } \\
\text { the first } \\
\text { factor } \\
\text { (formal } \\
\text { knowledge) }\end{array}$ & $\begin{array}{c}\text { Factor } \\
\text { loadings of } \\
\text { the second } \\
\text { factor } \\
\text { (service } \\
\text { orientation) }\end{array}$ & $\begin{array}{l}\text { Commu- } \\
\text { nality }\end{array}$ \\
\hline $\begin{array}{l}\text { Share of persons ages } 25-59 \text { with a high c } \\
\text { medium educational attainment (\% of the } \\
\text { total age group; 2000) }\end{array}$ & 66.44 & 17.61 & 0.87 & 0.05 & 0.75 \\
\hline GERD (1997) & 1.61 & 1.02 & 0.84 & 0.04 & 0.70 \\
\hline $\begin{array}{l}\text { Share of employment in knowledge- } \\
\text { intensive services (ISIC Rev.3: I61, I62, } \\
\text { J67, K70-K74, M80, N85, 092; \% of tota } \\
\text { employment; 1999) }\end{array}$ & 32.00 & 8.08 & 0.72 & 0.60 & 0.89 \\
\hline $\begin{array}{l}\text { Industrial employment (\% of total } \\
\text { employment; 2000) }\end{array}$ & 28.89 & 7.15 & 0.15 & -0.93 & 0.89 \\
\hline Service employment (\% of total; 2000) & 66.73 & 8.66 & 0.40 & 0.86 & 0.89 \\
\hline
\end{tabular}

No. of European NUTS-2 regions: 203.

GERD: Gross domestic expenditure on research and development in \% of gross domestic product

ISIC: International Standard Industrial Classification.

Method of extraction: Principal components analysis.

Method of rotation: Varimax.

Source: Own calculations on the basis of data provided by European Communities/Eurostat, various years:

Regions. Statistical Yearbook. Luxembourg: Office for official publications.

On the basis of the five variables described in Table 1, a factor analysis was performed for 203 of the 211 European NUTS-2 regions. Two factors with an eigenvalue of more than 1 emerged. These two factors explain $82 \%$ of the initial variance. Both of them are strongly correlated with three of the variables (cf. Table 1). These correlations suggest that the first factor can be used as an indicator for the qualificational basis of the region. A high level of employees with a upper secondary or tertiary qualification, a high share of research and development expenditure (GERD) and a high share of employment in knowledge-intensive services indicate the importance of formally certified, abstract qualifications and systematic innovation activities. The second factor points to the relative impact of industrial in comparison to service-based forms of production and organization. As it will be shown later, this factor refers also to the relative importance of tacit, especially production-related competencies.

The values for the two factors can be calculated for each region. These regional factor scores cluster within a nation: For illustrative purposes the values for the 203 regions can be aggregated on the national level (Figure 1). 
Figure 1: $\quad$ Regional capabilities in 15 EU countries. Nationally aggregated regional factor scores

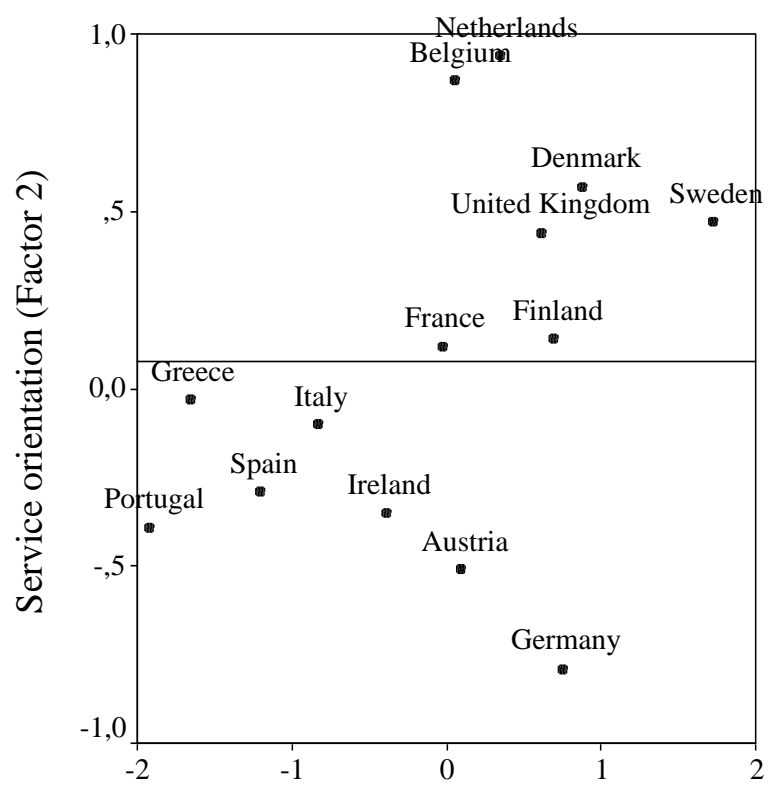

Formal Knowledge (factor 1)

Source: Own calculations on the basis of the factor analysis described in Table 1 and in the text.

This data shows that the Scandinavian, Dutch, Belgium and British regions are characterized by a relatively strong service sector and a qualified labour force, whereas the Mediterranean regions are characterized by a higher proportion of low-skilled inhabitants and a higher share of industrial employment. Germany and Austria France are in a different position. Their service sector is much smaller while the formal qualification of its population is nearly as high as in the service-oriented economies of northern Europe.

In the next step, we will analyse the patterns of labour market inclusion and exclusion within this two-dimensional space of regional capabilities taking as an indicator selected ageand gender-specific employment and unemployment rates. In the case of older people, the difference between the employment rates of 55-64 year old population and the core age group (35-44 years) is taken as an indicator. For younger people, the unemployment rates are a more adequate indicator for exclusion ${ }^{4}$ processes, because the low employment rates of younger people can also be the result of a prolonged participation in the educational system. Women either be constrained to non-paid jobs (childcare, etc.) or they can be unemployed. These two forms of labour market exclusion are indicated by gender-specific differences of the employment and unemployment rates. 
Table 2: $\quad$ Regional capabilities and labour market exclusion of women, younger and older people (203 European NUTS-2 regions)

\begin{tabular}{|c|c|c|c|c|c|}
\hline & $\begin{array}{c}\text { Employment } \\
\text { rate (\% of } \\
\text { population } \\
\text { aged } 15-64), \\
2000\end{array}$ & $\begin{array}{c}\text { Difference } \\
\text { between the } \\
\text { employment } \\
\text { rates of men } \\
\text { and women } \\
\text { (\% of total; } \\
2000)\end{array}$ & $\begin{array}{l}\text { Difference } \\
\text { between the } \\
\text { unemploy- } \\
\text { ment rates of } \\
\text { men and } \\
\text { women (\% of } \\
\text { total; } 2000)\end{array}$ & $\begin{array}{c}\text { Difference } \\
\text { between the } \\
\text { average and } \\
\text { the youth } \\
\text { unemploy- } \\
\text { ment rates } \\
\text { (\% of total; } \\
\text { 2000) }\end{array}$ & $\begin{array}{c}\text { Difference } \\
\text { between the } \\
\text { employment } \\
\text { rates of the } \\
35-44 \text { and the } \\
55-64 \text { year } \\
\text { old } \\
\text { population } \\
(2000) \\
\end{array}$ \\
\hline Constant & $61.18^{* * *}$ & $16.57 * * *$ & $4.83 * * *$ & $13.73 * * *$ & $35.34 * * *$ \\
\hline GDP/head (PPS), 2000; EUR15=100 & 0.04 & 0.02 & -0.02 & $-0.05 *$ & $0.09 *$ \\
\hline Formal Knowledge (factor 1) & $3.91 * * *$ & $-6.59 * * *$ & $-3.21 * * *$ & $-2.82 * * *$ & -1.02 \\
\hline Service orientation (factor 2) & -0.39 & $-1.23 * *$ & -0.002 & $1.71 * * *$ & $-1.97 *$ \\
\hline$\overline{\mathrm{R}^{2} \text { (corr.) }}$ & $0.283 * * *$ & $0.574 * * *$ & $0.468 * * *$ & $0.24 * * *$ & $0.035^{*}$ \\
\hline
\end{tabular}

Linear regression models. Level of significance: * : $5 \%$; **: $1 \%$; ***: $0.1 \%$.

Source: See Table 1.

In Table 2, the results of five linear regression models are shown. The dependent variables are the total employment rate and the four exclusion variables just mentioned. The independent variables are the two factor described in Table 1. The GDP per capita is used as a control variable. These regressions show that the inclusion of women in the labour market is strongly correlated with the first factor, indicating the effects of a higher education. This confirms that women are the principal winners of the educational expansion. The same is true for younger people. Their inclusion in the labour market is facilitated by formal qualifications. This explains why the total employment rate strongly depends on the share of persons with a high or medium educational attainment. This variable, however, does not significantly influence the relative share of older employees. Other aspects of labour market institutions, for example public pre-pension schemes, may be more important.

However, the labour market involvement of women and young people also depends on whether the respective region is service or industry oriented. In service-oriented regions, the relative employment rates of women and older people as well as the unemployment rates of younger people are higher. For a thorough interpretation of these facts, much more details on the regions and their labour markets would be necessary. A reasonable first interpretation of these results could be that employment in industry-oriented sectors are accompanied by specific forms of labour market segmentation, which account for the exclusion of female and

$4 \quad$ The concepts of inclusion and exclusion in the article always refer to labour market inclusion or exclusion without denying the possibility that actors excluded or included in labour markets are also 
older employees and the inclusion of younger ones. These forms of labour market segmentation are the result of strategies of social closure, which limit the access to privileged occupational positions to skilled male industrial workers. Younger workers are also relatively privileged by these patterns of segmentation because the transition from school to work is facilitated in German-speaking and Scandinavian countries by a system of vocational training. On the one hand, these forms of labour market segmentation are the basis for the exclusion of women and other groups, on the other hand, they are the basis for the accumulation and intergenerational transmission of work-related, experience-based skills. This is a major advantage of closed labour markets, examples of which are the professional and internal labour markets. Even if segmented labour markets are no specificity of industrialized regions, industrial forms of production are apparently more dependent on the accumulation of experiences and practical skills than services.

In conclusion, the available data shows that two dimensions of regional capabilities can be distinguished for more than 200 European regions. The first dimension is formalised knowledge, which is the product of systematic education and of systematic research and development activities. The second is industrialised forms of production, where tacit, experience-based forms of knowledge apparently play a somewhat larger role than in servicebased forms of production. The first factor is strongly negatively correlated with the exclusion of female and young people indicating the inclusive nature of regional capabilities based mainly on formalized, explicit knowledge. The second factor is linked to the exclusion of female and older people and the inclusion of younger employees thus illustrating the specific patterns of labour market segmentation mainly in the highly-industrialized, German-speaking European countries.

For the European Employment Strategy previously discussed, this means that a higher level of inclusion of females, and younger and older people in the labour market may threaten the production-related, experience-based skills that have been previously generated and transmitted in segmented, exclusive labour markets. Therefore, the development of an alternative, less exclusive labour market regime, especially in Mediterranean and Continental European countries, requires not only a reorganisation of the labour market, but also different educational and production concepts. Forms of production more strongly based on explicit, transferable qualifications would be required to facilitate a shift to a more inclusive labour market, which is the primary target of the EES. This could be achieved if the organisations and regions involved increase their innovativeness. Therefore, the employability approach of 
the EES should be complemented by a capability approach, which attempts to strengthen the innovative capacities of regional production systems. Whether or not and how this may be possible will be discussed in the following section.

\section{The Political Support of Regional Capabilities. Limits and possibilities of Cluster Policies}

Besides the provision for an adequate regional "knowledge infrastructure" (research and development, technology transfer infrastructures, education, training), regional patterns of cooperation and competition are a crucial feature of regional innovation systems. These patterns can be politically facilitated on three different levels. Firstly, the state can create institutions on the national level that promote the development of co-operation and relationship networks across the boundaries of an industrial branch. Secondly, the same idea can be applied on the regional level. Thirdly, attempts can be made to directly create inter-organisational cooperation networks. Therefore, cluster policies can be concentrated on the national level, on the regional level and on the micro level of concrete co-operation networks. Their main objective is the selection and sometimes the creation of new, promising networks. We will illustrate the corresponding political conceptions with the aide of some case studies reported in Braczyk et al. (1998) and OECD (1999).

\subsection{National cluster policies}

A national cluster policy could be particularly interesting for countries with close interindustrial production and value chains. In this case, it would be important to overcome traditional industrial boundaries through an economic, research and technology policy that fosters patterns of co-operation across the traditional boundaries of branches and areas of technology. An example of this is Denmark, a country with a relatively high share of smaller businesses. In Denmark, (nearly) the entire economy has been divided into six "resource areas”. These areas are separated into groups based on their commonly-known characteristics: food, consumer goods and leisure, construction and housing, communication, transport and supply industries, medico/health and general supplier businesses. In each of these resource areas, a co-ordination group was founded with the participation of businesses, employee representatives and public authorities. These co-ordination groups develop policy recommendations taken from the respective legislator or from specific committees. 
In Finland, the national economic policy is also designed to support knowledge-based economic clusters. For example, the public authorities promote the telecommunication cluster through targeted research and education politics and through the active support of the development of international standards for the industry. Furthermore, the state also acts as a demanding customer for the domestic industry. This does not mean primarily favouring domestic firms, but promoting products and standards that will also be attractive to foreign customers. A cluster policy on the national level therefore aims to orient the "knowledge base” of a country, its firms, research, training and education facilities, towards new demands and co-operation opportunities.

\subsection{Regional cluster policies}

On the regional level, public policies could be used to stimulate inter-organisational patterns of co-operation and regional innovation networks through research and technology centres and technology transfer facilities. An example of this is Wales (Cooke 1998b). After the decline of the mining industry, foreign companies opened new engineering, electronics and automotive plants. Through innovation and technology transfer centres, science and technology parks, supplier networking initiatives, and joint research initiatives and education facilities, the Welsh Development Agency and other public authorities tried to promote new linkages and networks between the newly settled production plants and local firms and institutions, which were already in place. In this way, the foreign plants were used as focal points for the creation of new industrial clusters. At the end of the 90s, job losses in the larger manufacturing firms exposed the limitations of these attempts.

Another example of a regional cluster policy is the ERVET system in the central Italian region of Emilia-Romagna. The industrial districts of this region are based to a considerable extent on small enterprises. Over 40 per cent of the regional industrial personnel work in enterprises with less than 20 employees. Such firms do not have the productionrelated services necessary for the development and subsequent global commercial exploitation of new products. However, many firms in the same branch are concentrated around one single town. The food industry is concentrated in the province of Parma, clothing in Carpi and Modena, shoes in Fusignano, furniture in Forli, ceramics in Sassuolo. Therefore the region Emilia-Romagna decided to support these industries through nine regional competence centres. These competence centres are concentrated in the ERVET organisation. Part of ERVET is a quality control centre, a centre for the shoe and leather industry, a centre for agriculture machines and a centre for the textile and clothing industry. These centres are 
jointly administered by the region, the relevant business associations and by nearly 1,000 firms. Costs were divided almost equally between private firms (34 per cent), the region (36 per cent) and national and European sources (30 per cent). The main function of such centres is to provide information and services that small regional firms cannot feasibly manage or sufficiently finance alone. Such competence centres strengthen the economic profile of a region. They are the expression of a common local pattern of development, thus facilitating the co-ordination, orientation, motivation and legitimisation of local entrepreneurial efforts. However, this example also demonstrates the limits of an exclusively regional orientation. Regional competence centres cannot overcome deficiencies in national infrastructures, particularly in the fields of education, professional training and research.

\subsection{Local cluster policies}

At the local level, public authorities could attempt to directly create and stabilise interorganisational patterns of co-operation. A prominent example for this is the promotion of networks between small enterprises by the Danish Technology Institute. Between the years of 1989-92, a program was created and initiated to support inter-company networks. The involved firms and 40 network moderators (comprised of local consultants, agencies and associations) created over 300 such networks. The aim of this program was to improve the flow of information and co-operation between smaller businesses, and thus overcome some of their most notorious weaknesses: small purchase volumes, inadequate marketing capacities and limited research and development potentials. These networks made it easier for the smaller businesses to observe the market and technological development, and to initiate joint research projects and share expensive equipment. This also allowed these firms to specialise in complementary tasks. This network moderator program was broadened to other areas (tourism, environmental technology, export support) after 1992. However, a further evaluation of these network programs exposed their disadvantages. The costs per network were very high, and numerous networks could not be stabilised after the end of the initial public financial support. This points to the important role of common institutions such as the Joint Venture Silicon Valley Network, the Italian ERVET system or the German chamber of commerce in effectively stabilising such inter-company networks.

The experiments with cluster policies conducted in Germany, mostly since the mid1990s, are mainly oriented towards the direct creation of co-operation networks. For illustration purposes, we will mention three of them: Structural policies in North RhineWestphalia, and the national Bioregio- and Innoregio programs. North Rhine-Westphalia, our 
first example, has the longest experience with regional economic and structural policies. Regional innovation and technology projects have been developed since 1987 as a reaction to the crisis of the coal and steel industry in the Ruhr area. An evaluation of these projects questioned the strong similarity between different regional development projects. They did not reflect regional specificity. It also stressed the overwhelming importance of more basic and conventional improvement measures such as improving the traffic infrastructure, providing sites for new firms and setting up technology transfer facilities (Heinze and Voelzkow 1997). In 1994, a second generation of 35 regional projects was started. This time the major objective was to create and strengthen networks between firms, associations, research and development centres, public authorities, schools and universities (Rehfeld, Baumer and Wompel 2000). In 1996 the Federal Research Ministry started the successful Bioregio project designed to support the most efficient biotechnology regions in Germany. It has been claimed that this program has produced considerable regional synergies, and has brought these regions closer to the level of the more advanced European and American biotechnology regions. Thirdly: In 1999, the Federal Research Ministry once again initiated a similar program, the Innoregio project. The target areas are 25 selected regions in eastern Germany, and address various branches. These regions will be supported until 2005 to the tune of 250 million Euro. The Federal Ministry anticipates that this program will foster the creation of inter-organisational networks and co-operations. In all three mentioned cases, the aim is to create new regional capabilities by linking regional actors in different ways. The Bioregio-program was especially successful because it was able to create new patterns of cooperation between existing universities, clinics, research institutes, pharmaceutical and chemical companies.

In conclusion, cluster policies can successfully support strategies, which are implemented to react to new challenges within the continuity of previous regional capabilities and development directions. In many cases, however, completely new technologies and organisations are needed in order to successfully cope with new situations. For example, the current strength of the manufacturing industry in Baden-Württemberg seems to be the result of the successful merging of old and new technologies, of mechanical engineering, car production, information technology, new materials, micro-system technology and optoelectronic systems. Therefore, there are no simple recipes for a successful cluster policy. Just as spatial proximity is no guarantee for a close co-operation between firms and their clients, suppliers and competitors; stable co-operation networks are no guarantee for reciprocal 
learning. Inter-company networks may also prevent learning and even support unsuccessful technological trajectories.

The theoretical basis for cluster policies should be an evolutionary understanding of regional strengths, weaknesses and trajectories. On one hand, it would be absurd to assume that political intervention could create a successful economic cluster in the middle of nowhere. Experiences in eastern Germany have shown that even with an enormous amount of money, it is difficult to create a competitive industrial base. On the other hand, there is no room for political fatalism. Political intervention can have a considerable, if sometimes unintended, impact on the development of new clusters.

\section{Conclusion}

The crucial objective of the European Employment strategy is to create more inclusive labour markets. More specifically, the employment rates for women, and younger and older people should be increased. Currently, the local and regional levels of the EES play a minor role in comparison with the national level. This is a major disadvantage for three different reasons. First, the regional level is essential in the creation of jobs in the social services area. The second disadvantage is that the regional level is the best suited target for innovation-centred policies. Finally, increased regional innovativeness has the potential of increasing the inclusiveness of the labour markets.

The possible link between innovation and inclusion has been discussed in three steps. In the first step, it was pointed out that productive and innovative capabilities very often are regionally concentrated. This was reported not only for the jewellery, steel, coal, ceramics, wood, paper, leather, shoes, clothing and textiles industry, but also for the vehicle and mechanical engineering industry, for financial services, information technology, for multimedia, biotechnology, advertisement and other cultural products. The reason for this occurrence can be divided into four groups, which have already been proposed by Alfred Marshall: the availability of local resources, transaction cost advantages, specialisation advantages and learning and innovation advantages. These regional capabilities evolve in an path-dependent manner.

In the second step, it was demonstrated that the regional level may play also a major role for labour market inclusion. We have tried to show that regional capabilities in more than 200 European NUTS-2 regions can be analysed in two dimensions. These dimensions are the “knowledge dimension”, in which Mediterranean were distinguished from other European 
countries and points to the importance of formal, explicit knowledge - for example in higher education, in research and development or in knowledge-based services; and the second dimension, which distinguishes between regions with a higher share of service employment and regions with a high share of industrial production (especially in southern und continental European countries) thus highlighting the role of implicit knowledge usually created, reproduced and reproduced in relatively closed labour markets. These forms of implicit knowledge seem to continue to carry more weight in industrial production than in servicebased forms of production. A higher level of inclusion of females and younger people is positively correlated with a higher educational level in the regional population, higher $R \& D$ expenditures and a higher share of service production. More inclusive labour markets may therefore require an encompassing re-orientation of industrial and educational strategies; for example, with a shift towards more knowledge-based forms of production and services.

Finally we illustrated the possibilities and limitations of successful political initiatives that could work to promote regional innovation systems. The success of economic regions depends to a considerable extent on previously accumulated competencies and on previously established patterns of co-operation. Political interventions can only influence the innovative capabilities, where previous regional trajectories have already laid the appropriate foundation. Nevertheless, a cluster policy can influence the development of regional competencies and patterns of co-operation both directly, through the political support of co-operation networks, and indirectly, through the creation of national and regional institutions. A regional cluster policy could therefore play an important role in creating jobs within a European strategy for employment that aims to facilitate the required, complementary reorientation to knowledgebased production forms. The political support of regional learning and innovation processes could work to facilitate a higher inclusion of relatively disadvantaged groups. The creation of more inclusive labour market regimes and the intended shift towards a more knowledge-based forms of production therefore could be mutually reinforcing - especially at the regional level.

\section{Bibliography}

Amin, Ash 1999, "An Institutional Perspective on Regional Economic Development", International Journal of Urban and Regional Research 23: 365-378.

Asheim, Bjørn T. and Isaksen, Arne 2002, „Regional Innovation Systems: The Integration of Local 'Sticky' and Global 'Ubiquitous' Knowledge”, The Journal of Technology Transfer 27: 77-86.

Braczyk, Hans-Joachim, Cooke, Philip and Heidenreich, Martin (eds.) 1998, Regional Innovation Systems, London, UCL-Press.

Chandler, Alfred D. 1992, „Organisational Capabilities and the Economic History of the Industrial Enterprise”, Journal of Economic Perspectives 6: 79-100.

Cooke, Philip 1998a, „Introduction: Origins of the concept”, in Braczyk, Hans-Joachim, Cooke, Philip and Heidenreich, Martin (eds.) 1998, Regional Innovation Systems, London, UCL-Press, pp. 2-25. 
Cooke, Philip 1998b, „Global Clustering and Regional Innovation: Systemic Integration in Wales” in Braczyk, Hans-Joachim, Cooke, Philip and Heidenreich, Martin (eds.) 1998, Regional Innovation Systems, London, UCL-Press, pp. 245-262.

Cooke, Philip 2002, Knowledge Economies. Clusters, learning and cooperative advantage, London; New York, Routledge.

de la Porte, Caroline, Pochet, Philippe and Room, Graham 2001, „Social benchmarking, policy making and new governance in the EU”, Journal of European Social Policy 11: 291-307.

Edquist, Charles (ed.) 1997, Systems of innovation: technologies, institutions and organizations, London, Pinter.

Ferrera, Maurizio, Matsaganis, Manos Sacchi, Stefano 2002, „Open coordination against poverty: the new EU 'social inclusion process'”, Journal of European Social Policy 12: 227-239.

Goetschy, Janine 1999, „The European Employment Strategy: Genesis and Development”, European Journal of Industrial Relations 2: 117-138.

Hall, Peter A., and Soskice, David (eds.) 2001, Varieties of Capitalism : The Institutional Foundations of Comparative Advantage, Oxford, Oxford University Press.

Hassel, Anke, and Hoffmann, Reiner 2000, „National Alliances for Jobs and Prospects for a European Employment Pact”, Brussels, Discussion and Working Papers of the European Trade Union Institute (DWP 2000.01.01 (E) (www.etuc.org/ETUI/Publications/DWP/default.cfm; accessed 12/92003).

Heinze, Rolf G. and Voelzkow, Helmut (eds.) 1997, Regionalisierung der Strukturpolitik in NordrheinWestfalen“, Opladen, Westdeutscher Verlag.

Hodson, Dermot, and Maher, Imelda 2001, „The Open Method as a New Mode of Governance”, Journal of Common Market Studies 39: 719-746.

Keller, Berndt 2000, „The new European employment policy or: Is the glass half-full or half-empty?”, in Hoffmann, Rainer, Jacobi, Otto, Keller, Berndt and Weiss, Manfred (eds.): Transnational Industrial Relations in Europe, Düsseldorf, edition of the Hans Böckler Foundation, pp. 29-44.

Le Galès, Patrick, Voelzkow, Helmut 2001, „Introduction: the Governance of Local Economies”, in Crouch, Colin, Le Galès, Patrick, Trigilia, Carlo, and Voelzkow, Helmut 2001, Local Production Systems in Europe. Rise or Demise? Oxford, Oxford University Press, pp. 1-24.

Marshall, Alfred 1982 [1890], „Principles of Economics”, reprint of the eighth edition 1920, Philadelphia, Porcupine Press.

Mosher, James S., and Trubeck, David M. 2003, „Alternative Approaches to Governance in the EU: EU Social Policy and the European Employment Strategy”, Journal of Common Market Studies 41: 63-88.

Nelson, Richard R. 1995, „Recent Evolutionary Theorizing About Economic Change”, Journal of Economic Literature 33: 48-90.

OECD (ed.) 1999, Boosting Innovation: The Cluster Approach, Paris, OECD.

Piore, Michael J., and Sabel, Charles F. 1984, The Second Industrial Divide. Possibilities for Prosperity, New York, Basic.

Platzer, Hans-Wolfgang 1999, „Die EU-Sozial- und Beschäftigungspolitik nach Amsterdam: Koordinierte und verhandelte Europäisierung? Integration 22: 176-190.

Rehfeld, Dieter, Baumer, Doris and Wompel, Mag 2000, Regionalisierte Strukturpolitik als Lernprozess, Graue Reihe des Instituts Arbeit and Technik No. 11/2000 (http://iat-info.iatge.de, accessed 12/92003).

Sabel, Charles F., Herrigel, Gary B., Deeg, Richard, and Kazis, Richard 1989, „,Regional prosperities compared: Massachusetts and Baden-Württemberg in the 1980s", Economy and Society 18: 374-404.

Scharpf, Fritz W. 2002, „The European Social Model. Coping with the Challenges of Diversity”, Journal of Common Market Studies 40: 645-70.

Sen, Amartya 1993, „Capability and Well-being, in: Nussbaum, Martha and Sen, Amartya (eds.), The Quality of Life, Oxford: Clarendon Press, pp. 30-53.

Storper, Michael 1997, The regional world : territorial development in a global economy, New York/London: Guilford Press.

Storper, Michael, and Salais, Robert 1997, Worlds of Production”, Cambridge, Harvard University Press.

Strambach, Simone 2002, „Change in the Innovation Process: New Knowledge Production and Competitive Cities-The Case of Stuttgart”, European Planning Studies 10: 215-231.

Streeck, Wolfgang 1991, „On the Social and Political Conditions of Diversified Quality Production”, in: Matzner, Egon, and Streeck, Wolfgang (eds.), Beyond Keynesianism: The Socio-Economics of Production and Full Employment, Aldershot/Brookfield, Edward Elgar, pp. 21-61.

Teece, David J. 1998, „Capturing Value from Knowledge Assets: the New Economy, Markets for Know-How, and Intangible Assets”, California Management Review 40: 55-79.

Teece, David J., Pisano, Gary and Shuen, Amy 1997, „Dynamic Capabilities and Strategic Management”, Strategic Management Journal 18: 509-533. 